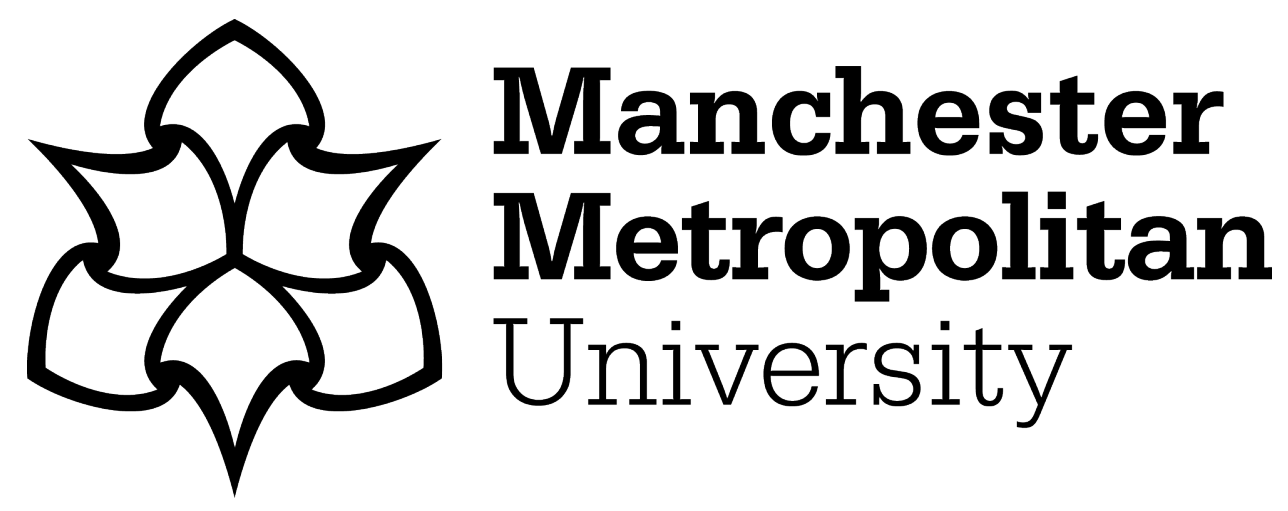

Currie, Graeme, Davies, Julie ORCID logoORCID: https://orcid.org/00000002-6875-3100 and Ferlie, Ewan (2017) A Call for University-Based Business Schools to "Lower Their Walls:" Collaborating With Other Academic Departments in Pursuit of Social Value. Academy of Management Learning \& Education, 15 (4). pp. 742-755. ISSN 1537-260X

Downloaded from: https://e-space.mmu.ac.uk/623819/

Version: Published Version

Publisher: Academy of Management

DOI: https://doi.org/10.5465/amle.2015.0279

Please cite the published version 


\title{
A Call for University-Based Business Schools to "Lower Their Walls:" Collaborating With Other Academic Departments in Pursuit of Social Volue
}

\author{
GRAEME CURRIE \\ University of Warwick, United Kingdom \\ JULIE DAVIES \\ University of Huddersfield, United Kingdom \\ EWAN FERLIE \\ King's College London, United Kingdom
}

\begin{abstract}
The walls around many business schools remain high, eroding interdisciplinary education and research collaboration that might address some grand challenges facing society. In response, we adopt a public interest perspective and argue business schools should lower their walls to engage with other academic departments to address such grand challenges in a way that engenders social value. We identify forces for lower and higher walls that surround business schools and influence prospects for interdisciplinary collaboration. We highlight examples of successful relationships between business schools and other academic departments, which offer some optimism for a reimagined public interest mission for business schools. Finally, we draw out some boundary conditions to take a more contingent view of possibilities for such interdisciplinary collaboration encompassing business schools.
\end{abstract}

Business schools should engage more with disruptive developments or "grand challenges" in the socioeconomic world, such as financial crises and their economic and societal effects (Starkey, 2015), as well as climate change, migration, and the global gap between the rich and poor (McKiernan \& Wilson, 2014). They need to think "bigger" and in a more

The authors contributed equally and are listed alphabetically. We are grateful to Ken Starkey, guest coeditor, and the three anonymous reviewers for their constructive feedback during the review process. We would like to thank Stephen Swailes and participants in the 2015 EFMD Higher Education Research Conference hosted by Said Business School, Oxford University, for their helpful comments on earlier versions of this article. Graeme Currie's time in the analysis and writing of this manuscript was funded by NIHR CLAHRC West Midlonds. creative and holistic manner than many schools do at the moment. Traditional business school structures should be broken down and reimagined for more open and collaborative behaviors with greater reach, respect, and relevance in addressing these grand challenges (Carlile, Davidson, Freeman, Thomas, \& Venkatraman, 2016). Taking this broad theme, here we specifically argue that business schools should "lower their walls" to collaborate more with other academic departments and embed their research-based activity more deeply within the wider university in pursuit of these worthy and inspiring "grand challenges." They should, in our view, also develop forms of management education and research that benefit the public interest, as well

Copyright of the Academy of Management, all rights reserved. Contents may not be copied, emailed, posted to a listserv, or otherwise transmitted without the copyright holder's express written permission. Users may print, download, or email articles for individual use only. 
as private corporate interests (Morsing \& Rovira, 2013; Muff, Dyllick, Drewell, North, Shrivastava, \& Haertle, 2013; Starkey, Hatchuel, \& Tempest, 2009).

The argument for the greater academic embedding of the business school within its host university is longstanding. A French professor visiting U.S. business schools in the late 1950s recommended that "a closer collaboration between the business schools and the other faculties would prove beneficial to all" (Tallon, 1959: 30). However, he went on to highlight the absence of such collaboration: "Most business schools, after acquiring their autonomy, try to preserve it by holding themselves aloof; there is no coordination with related departments, such as the Law School" (Tallon, 1959: 30). Noting that business school collaboration with other academic departments remains "a neglected area of empirical inquiry and one demanding future investment" (Pettigrew, Cornuel, \& Hommel, 2014: 4-5), we revisit Tallon's assertion 57 years on from his U.S. visit, and will analyze forces that cause business schools to maintain "high walls" around them, so they remain isolated and fail to collaborate with other university departments. At the same time, we highlight other influences that potentially support the "lowering of walls" and present empirical examples of such, where business schools do appear to collaborate with other university departments.

Our analysis is set out as follows: First, we chart the trajectory of business schools across three phases from their beginnings to the present day, with a focus on their evolving orientation toward practice, theory, and collaboration with other academic departments. Within the current third phase, we identify the emergence of debate about a potential "public interest" model for the business school that argues for greater interdisciplinary collaboration (Ferlie, McGivern, \& De Moraes, 2010) upon which we build. We then consider different analytic levels regarding barriers (engendering higher walls) and supporting features (engendering lower walls) that influence the extent to which business schools might engage in interdisciplinary collaboration to address "grand challenges" highlighted earlier. Regarding lowering walls, we provide some empirical examples of university-based business schools that collaborate with other academic departments in their host university and we discuss significant contingencies that shape this. We conclude by exhorting business schools to lower their walls where the context for this strategy is receptive. Finally, we advocate further research that explores the boundary conditions affecting collaboration between business schools and other academic departments within their host university.

\section{THREE TIME PERIODS: PURSUIT OF SOCIAL VALUE}

We identify three time periods in the development of business schools in terms of their evolving orientation toward addressing grand challenges. We argue their first phase of development was one shaped by large-scale industrialization and the growth of large corporations, with business schools expected to enhance managerial capability to support economic growth. Khurana (2007) characterizes this period as a professionalization phase for business schools, in which knowledge was not only transferred to support the development of capability among the emerging managerial cadre, but professional ideals of management were also reinforced about wider public interest (Parsons, 1951). The early business schools were essentially pursuing a professionalization project for the rising occupation of management, taking the cases of medicine and law as role models (Khurana, 2007). In general terms, therefore, business schools were expected to adopt a stance of serving the public good (Alajoutsijörvi, Juusola, \& Siltaoja, 2015)—albeit narrowly defined toward improving managerial capability for national economic advantage (Whitley, 1988)-to legitimate their professionalization project. However, there was increasing criticism of business schools' contribution toward developing managerial capability for national economic advantage, with particular concern about the impact of business schools on scientific and technological advances, which the United States required to compete with the Union of Soviet Socialist Republics in the "space race" (Augier \& March 2011; Khurana, 2007). Increasing unease about the practical irrelevance of U.S. business schools was reflected in two high profile reports about business education in the late 1950s (Gordon \& Howell, 1959; Pierson, 1959). Outside the United States, we note a process of uneven and lagging development. For example, it was only in the 1960s that the United Kingdom established its first business schools in Manchester and London (British Institute of Management, 1963). The development of business schools in countries such as the United Kingdom also pursued a professionalization project, which was similarly criticized for failure to develop managerial capability for national economic advantage (Porter \& McKibbin, 1988). 
In a second phase of business schools' development, which we date from the 1980s onward, confusion about their mission appears to reign. On the one hand, business schools became increasingly concerned with building academic legitimacy as scientific actors in academia (Alajoutsijörvi et al., 2015). "Physics envy" (Flyvbjerg, 2001; Laumann, Gagnon, Michael, Michaels, \& Sennett, 1995) was generated among business school faculty, who attempted to become more theoretically oriented and abstract (Alajoutsijörvi et al., 2015; Thomas \& Wilson, 2009). The result was that "many leading B schools ... quietly adopted an inappropriate-and ultimately self-defeating-model of academic excellence. Instead of measuring themselves in terms of the competence of their graduates, or by how well their faculties understand important drivers of business performance, they measure themselves almost solely by the rigor of their scientific research" (Bennis \& O'Toole, 2005: 98). This drift toward privileging theory development further undermined the legitimacy that business schools had previously derived from their practical relevance, which provided some degree of social value (Bennis \& O'Toole, 2005; Currie \& Knights, 2003; Khurona, 2007; Thomas \& Wilson, 2009).

On the other hand, investor capitalism came to the fore in this period, when business schools increasingly focused on research and education to maximize shareholder value. Thus, business schools increasingly served a norrow copitalist interest, and wider stakeholders' interests were rendered marginal (Dunne, Harvey, \& Porker, 2008; Khurana, 2007). Where the two forces-the theoretical emphasis and investor-based capitalism-came together, business schools increasingly produced a body of knowledge founded on highly technical econometrics designed to support the development of novel financial instruments for financial institutions, which rendered them "complicit in the current financial crisis" (Currie, Knights, \& Starkey, 2010: 1). This stance was associated with the strong growth of finance groups in some schools in the 1980s and 1990s.

Meanwhile, in the United Kingdom in particular, these forces worked in opposition and sometimes resulted in a split, where some business schools oriented themselves toward activity "for" management (such as London Business School and Warwick Business School). Others, often symbolically described themselves as "management schools" rather than "business schools" (such as the University of Leicester's School of Management and Lancaster University Management School). The latter were keen to exhibit critical management credentials and preoccupied themselves with activity "about" management as the effects of the Thatcher-led Conservative party government rippled through the university sector in the 1980s, and academics from other social science disciplines, such as sociology, found they were displaced to business schools (Currie, Dingwall, Kitchener, \& Woring, 2012; Currie \& Knights, 2003; Grey, 2004). Such a schism in the United Kingdom generated further confusion across a wide range of stakeholders (McKiernan \& Wilson, 2014; Starkey \& Tiratsoo, 2007; Thomas \& Wilson, 2009).

In the first two phases of business schools' development, exogenous influences shaped their research and teaching activity. In the United States, during the first phase of the development of business schools, the growth of large corporations was a major influence, while in a second phase, business schools appear to have been more shaped by their relationships with other disciplines. At the same time, investor capitalism focused interactions in business schools with a particular mode of financialized educational and research practice. Meanwhile, in the United Kingdom, there was less growth in large corporations between the mid-60s and the 1970s, and greater awareness of U.K. management's amateurism, and a lack of the professionalism required to fuel restructuring the economy (see LloydJones \& Lewis, 1998) both in business and the civil service (Lowe, 2011).

"Meanwhile, in the United Kingdom, there
was less growth in large corporations
between the mid-60s and the 1970s, and
greater awareness of U.K. management's
amateurism, and a lack of the
professionalism required to fuel
restructuring the economy (see Lloyd-Jones
\& Lewis, 1998) both in business and the civil
service (Lowe, 2011)."

We argue that a third phase of business school development is now apparent, which is again shaped by exogenous influences, but this time by widely held concerns about the increasingly complex global challenges, as apparent in such themes as emerging markets; radical technological innovation; aging populations; climate change; and globalized flows of trade, capital, and people: all 
problem areas that require interdisciplinary research (Ferlie et al., 2010; Jacobs \& Frickel, 2009; McKiernan \& Wilson, 2014; Muff et al., 2013; Starkey, 2015). These forces render the prior investor capitalism model unsustainable (Khurana, 2007). Further, business schools are viewed as complicit in corporate scandals, associated with investor capitalism such as Enron (Adler, 2002; Ferlie et al., 2010; Khurana, 2007; Starkey \& Tiratsoo, 2007). Business schools stand accused of "propagating ideologically inspired amoral theories" (Ghoshal, 2005: 76) and are blamed in part for the Global Financial Crisis (Currie et al., 2010; Locke \& Spender, 2011; Podolny, 2009). Thus, Khurana (2007) calls for a new business school model that addresses needs of a wider group of stakeholders beyond shareholders.

In this light, below we discuss Ferlie et al.'s (2010) proposal for a "public interest" model of the business school, which involves the pursuit of greater breadth and depth in interdisciplinary collaboration with other academic departments to engender a social value-based contribution from business schools working with a wider group of societal and academic stakeholders.

\section{THE PUBLIC INTEREST MODEL FOR BUSINESS SCHOOLS}

Ferlie et al. (2010) propose a "public interest" model as a response to the failure of prior business school models and the need for business schools to engage with wider social issues, which in turn reflect major public and policy concerns. They also affirm Pfeffer and Fong's (2004) view that business schools need to rediscover their roots as knowledge-producing university departments and should link to other university departments. Their analysis conceives business schools as a professionalization project (as in the first phase of their historical development), not cast in terms of market capture (Larson, 1979), but more as embodying core characteristics of ideal type professions oriented toward public good and societal interest (Parsons, 1951).

Although it has some similarities with the "agora" model (see Starkey et al., 2009), where the business school acts as an open meeting space for many stakeholders within a flexible and dispersed mode of knowledge production, the public interest model has a greater concern for the role of the business school within the university. It also exhibits greater attachment to-and privileging of $-a$ traditional peer-reviewed and publicly funded mode of (social) science, seen as promoting disinterested behavior from business school academics and located within a more traditional paradigm of Mertonian science. Thus a public interest model requires business schools to be more outward facing, and thus, lower their walls within the university (Ferlie, Currie, Davies, \& Ramadan, 2014).

In our reflections on this public interest model for business schools, we suggest business schools now have an exciting opportunity to work across many different academic departments if they possess the imagination, vision, and capability to do so. At the same time, we suggest some business schools might find this strategy easier to adopt than others. Below, we examine some antecedents that may influence whether business schools raise or lower their walls to collaborate (or not) with other university departments. We set out the following research questions:

$R Q 1$ : What are the forces that influence business schools to maintain "high walls" so they remain isolated and do not collaborate with other university departments?

RQ2: What are the antecedents for, and empirical examples of, "lower walls" where business schools collaborate more with other university departments?

As a starting point for developing a more systematic analysis of the factors that influence the height of a business school's walls, we consider possible constraints across the multiple levels of analysis set out below.

\section{FORCES FOR HIGH WALLS}

In this section we highlight the existence of institutional barriers to lowering walls of business schools in relation to their interactions with other university departments (Pettigrew et al., 2014). We discuss various levels of analysis in turn.

\section{The Supranational Influences of Accrediting Agencies and League Tables}

Despite their claims to encourage innovation and diversity (Starkey \& Tiratsoo, 2007), the influence of accreditation agencies, which operate on a supranational base, often raise the walls of business schools and erode collaboration with other academic departments. At first sight, their guidance for accreditation appears to encourage innovation, as shown in the 15 revised standards of AACSB 
International (2013), which are less prescriptive in terms of a template for business schools (Boyde, 2013; Starkey \& Tiratsoo, 2007). However, generally, accreditation pressures represent a threat to the diversity of business schools, pushing them toward mimetic strategies and isomorphism (Wedlin, 2007), and so act as a "regime" serving to preserve and perpetuate the status quo that benefits élite business schools (Lowrie \& Willmott, 2009). They drive business schools to avoid risks associated with radical innovation, such as collaboration with other academic departments (Julian \& Ofori-Dankwa, 2006; Lejeune \& Vas, 2014; Proitz, Stensaker, \& Harvey, 2004). In particular, some argue that current AACSB standards constrain collaboration with other academic departments because they stress a need for business school autonomy (Lowrie \& Willmott, 2009). Similarly, the European Quality Improvement System (EQUIS) accreditation process requires a business school to demonstrate that "it has reasonable autonomy in setting its strategic agenda and in managing its budget and that it has its own dedicated faculty and administrative staff" (EFMD, 2015: 5). These accreditation pressures encourage business schools to build high walls-perhaps complete with ramparts-to demonstrate institutional separation and independent decision making from the rest of the university.

Alongside the influence of accrediting agencies, such as AACSB International and EFMD, business school rankings, as manifested in global league tables showing school ronkings produced by Bloomberg Businessweek, The Financial Times, The Economist, and Forbes, have had a similar homogenizing and adverse effect upon potential collaboration (Rasche, Hommel, \& Cornuel, 2014). Encouraged by media-led ronkings, there are strong career incentives for faculty to develop narrow disciplinary specialization (Currie, El Enany, \& Lockett, 2014), given the low value often placed on interdisciplinary journals in such ronkings (Campbell, 2005).

\section{National Policy Influence}

National policy influences within the higher education sector may also encourage higher walls. This policy push is stark in the United Kingdom, where the government's Research Excellence Framework (REF, formerly the Research Assessment Exercise or RAE), which ranks all university departments against their peers every 7 years or so, privileges peer-reviewed publications within narrowly defined subject domains and journals and acts against interdisciplinary collaboration (Adler \& Harzing, 2009). This narrowing of publications and consequent effect upon interdisciplinary collaboration from research evaluation exercises extends to other nations, such as Australia, which has implemented Excellence in Research for Australia (ERA), and Italy, which has implemented the Italian National Agency for the Evaluation of the University and Research Systems (ANVUR). Although the U.S. government has stayed away from a similar interventionist stance, nevertheless, increasingly narrow lists of journals are prescribed for promotion purposes in U.S. business schools (Starkey \& Tiratsoo, 2007). The global effect is that business schools, and indeed other academic departments with which they seek to collaborate, organize their activities and research centers to maximize potential for a narrow set of high-ranked publications, and veer away from interdisciplinary journals (McKiernan \& Wilson, 2014).

\section{Intra-University-Level Tensions}

Relations between business schools, their host universities, and other academic departments may not be harmonious. Senior university managers may perceive business schools as attempting to create a corporate university within a university (Craig, Clarke, \& Amernic, 1999: 514). This perception can provoke a clash with university senior management that business school deans often lose. For example, deans at Manchester Business School and City University (now Cass) Business School in the United Kingdom both led unsuccessful campaigns for full autonomy from their host universities (Griffiths \& Murray, 1985).

Other university faculty may exhibit "business school envy" (Arbaugh, 2010), fueled by relatively high salaries for business school faculty (Augier \& March 2011; Davis, 2014). Because most business schools typically pay their professors, particularly their "research stars," more than the going rates elsewhere (Callie \& Cheslock, 2008; Ivory, Miskell, Neely, Shipton, \& White, 2007), this is also a way of maintaining the high walls because it locks their staff inside the institution, rather than encouraging them to engage with disciplinary kin in other academic departments. Further, the accompanying hype and overconfidence around the sub-brand of the business school (Gioia \& Corley, 2002) and its grandiose claims (Alvesson, 2013) may further alienate faculty in other departments as well as senior university managers. 


"Because most business schools typically
pay their professors, particularly their
"research stars," more than the going rates
elsewhere (Callie \& Cheslock, 2008; Ivory,
Miskell, Neely, Shipton, \& White, 2007),
this is also a way of maintaining the high
walls because it locks their staff inside the
institution, rather than encouraging them
to engage with disciplinary kin in other
academic departments."

We suggest higher walls are not just built from within the business school, but that they are also contributed to from without. Other disciplines, specifically sociology, have shown a declining interest in organizations, which means there are fewer opportunities for extramural activities with business school faculty members. Thus, organizational sociologists (and organizational psychologists) are more likely to be located in business schools with high walls around them (Porker, 2015).

The business school is subject to distinctive global market forces, threats from MOOCs, and alternative providers that regard business and management education as "low hanging fruit." Consequently, business schools may become "more 'business' and less 'school'" (Starkey \& Tiratsoo, 2007: 50) as they are forced to adopt competitive strategies that might appear alien to traditional academic departments where the marketplace is experienced differently. Foculty outside business schools may perceive the responses of business schools to such strong competitive forces as exhibiting characteristics of an anti-intellectual trade school with nothing of any wide-ranging interest to say beyond a narrow and crass concern with the determinants of a firm's economic performance (Cruikshank, 1987). The danger is that business schools become the academic equivalent of the Cayman Islands or other tax havens: rich, isolated, and under suspicion from the authorities.

\footnotetext{
"The danger is that business schools become the academic equivalent of the Cayman Islands or other tax havens: rich, isolated, and under suspicion from the authorities."
}

\section{Departmental-Level Influences}

Business school academics, with their varied disciplinary backgrounds, are well placed to engage in interdisciplinary collaboration to address disruptive global developments (McKiernan \& Wilson, 2014). Paradoxically, however, academics within a pluralistic enterprise, such as a business school, may not be incentivized to work in partnership with others outside the confines of a business school because they can collaborate "in house" across disciplines (Ferlie et ol., 2014). This phenomenon may be compounded by the spate of mergers, which act to create a critical mass of academics from different disciplines within larger schools. Examples include Thunderbird School of Global Management at Arizona State University (Clark, 2014); the merger of a business school, art college, and technology school to form Aalto University in Finland (Green, 2009); and consolidations, particularly in France (Bradshaw, 2013).

Exacerbating these tensions, business school deans frequently argue against a "one-size-fits-all" approach applied to them by the central university. Instead, they ask to be treated as a special case, predicated on the demands made by the business school's distinctive student body (Armstrong, 2003; Currie, 2007), for example, needing or having infrastructure for tailored careers support and corporate engagement that are part of the "wraparound" offering for premium fee graduate and pre- and postexperience programs. Thus, business schools may demand extra resources, beyond those available to other academic departments, based on the popularity of business and management education, high use of adjuncts, and healthy surpluses (Starkey \& Tiratsoo, 2007). In terms of internal tax regimes, many business school deans begrudge the significant subsidies contributed to the university center, which can disincentivize their own faculty. Raising walls, therefore, is a natural defense by these strategic actors to gain autonomy, avoid being exploited by the university, and protect what is commonly viewed as the "cash cow" (Starkey \& Tiratsoo, 2007). Top-ranked MBA programs in U.S. business schools may reflect this by tending to operate in disciplinary silos (Navarro, 2008).

\section{Disciplinary-Level Influences}

Interdisciplinary collaboration is challenging. Epistemic walls bound any one discipline with contestation rather than collaboration, commonly characterizing disciplinary interactions, and some disciplines as more powerful than others (Becher, 
1989, 1994; Choi \& Pak, 2007; Knorr-Cetina, 1999). Some epistemic communities may be more reluctant to engage in interdisciplinary research. Within a business school, economists appear more skeptical than other faculty-who have been drawn from sociology or psychology for example-of the value of interdisciplinary research (Pieters \& Baumgartner, 2002). Epistemic walls constructed by others can also inhibit any attempt at interdisciplinary collaboration. For instance, research carried out by business school faculty, who represent "newcomers" to health sciences research, may be undermined by being seen as too theoretical or lacking practical impact by clinical scientists (Currie, El Enony, \& Lockett, 2014). Although business school faculty can in principle contribute expertise about innovation and the organizational and system-level problems that pervade the poor implementation of best practice in healthcare settings, they might feel disinclined to do so where their inputs are marginalized by historically dominant epistemes, systems of knowing, found in that field (Currie et al., 2014; Ferlie et al., 2014). Such influences are reflected in a lack of engagement by business school faculty in interdisciplinary initiatives promoted at university level. For example, at the University of Warwick, despite the relatively large size and high status of the business school within the university, of 11 research grand challenges (labeled "Global Research Priorities" [GRPs]) funded by the host university, Worwick Business School faculty members are only significantly involved in three (www2.warwick.ac.uk/research/ priorities).

Further, even where opportunities exist across epistemic divides, business schools may be reluctant to engage in interdisciplinary collaboration. It could be that, rather than developing the business school as the hub of any collaboration, business school activity dissipates in relation to working jointly with other academic departments (Starkey \& Tiratsoo, 2007). The risk, then, is that instead of the business school absorbing other disciplines, perhaps other disciplines might absorb the business school. For example, in the late 19th and early 20th centuries, business education and research were encompassed within Columbia's School of Political Sciences.

\section{BUT CAN SOME NEWER FORCES HELP LOWER WALLS?}

Within this section, we highlight some recent influences that may mediate the institutional barriers outlined above and orient business schools toward lowering their walls.

\section{National Policy Influencing Grand Challenges}

At a national policy level, some recent policy pushes for lowering walls between academic disciplines (with subsequently indirect implications for business schools, which are here seen as an important subsector of the wider higher education system) are evident. In the United States, in response to calls for universities to address disruptive global developments, a plethora of initiatives has been aimed at enhancing interdisciplinary research. In 2006, the National Science Foundation launched an interdisciplinary training program for graduate research fellows called "Integrative Graduate Education and Research Traineeships." In 2007, the National Institutes of Health funded nine interdisciplinary research consortia to address health challenges by bringing in nontraditional approaches. Around the same period, Mellon Foundation New Directions Fellowships offered social sciences faculty the opportunity to acquire systematic training outside their own disciplines (Jacobs \& Frickel, 2009).

Similarly in the United Kingdom, science and research policy (and funding) has moved toward broad and thematic areas "as innovation is increasingly driven by challenges such as climate change and the ageing population ... [which require] interdisciplinary collaborations to develop new business models, products and processes" (BIS, 2011: 16). Such a government agenda has influenced business school faculty to demonstrate the explicit social, economic, and cultural value of their research (Khazragui \& Hudson, 2015; Lejeune, Davies, \& Starkey, 2015).

\section{Universities Influencing Grand Challenges}

Reflecting national policy influences, senior university managers to a greater extent steer various academic departments toward interdisciplinary research across thematic areas that represent grand challenges associated with disruptive global developments (Ferlie et al., 2014). As noted earlier, the University of Warwick in the United Kingdom has developed and resourced Global Research Priorities (GRPs) in 11 areas: behavioral science; connecting cultures; cybersecurity; energy; food; global governance; innovative manufacturing; international development; materials; science and technology for health; and sustainable cities (http:// www2.warwick.ac.uk/research/priorities/\#grp-p). In some areas (certainly not all), business school 
faculty are significantly engaged. Warwick Business School (WBS) takes the lead for the University's GRPs in behavioral science, bringing together not just social sciences departments such as economics and psychology, but also the Warwick Medical School and Warwick Manufacturing Group to address long-term health conditions through digital means. At University College London's (UCL) School of Management, students undertake two "scenario" weeks when they work in teams on real interdisciplinary management problems related to a UCL Grand Challenge such as global health and wellness (www.ucl.ac.uk/grand-challenges). Similarly, the $x$-lab (http://www.x-lab.tsinghua.edu.cn/en), which operates under the auspices of the School of Economics and Management at Tsinghua University, supports cross-disciplinary entrepreneurship (Bradshaw, 2014). Stanford Graduate School of Business actively promotes its collaborative efforts among the University's seven schools, with statements on its website explaining, "you might find a Stanford GSB marketing professor partnering with a colleague in neuroscience" (www.gsb.stanford. edu/stanford-gsb-experience/life/collaborativeenvironment). Meanwhile, business schools situated in technological universities (such as Cambridge Judge Business School, HKUST Business School, Imperial College Business School, KAIST, MIT Sloon School of Management, and UTS Business School) work with the well-developed science and engineering departments there. In some cases, business schools emerged from engineering departments in the first place (e.g., at Imperial College London), so historic links may continue.

The University of Oxford provides a particularly interesting example of the parent institution's strengths being drawn upon by Said Business School to pursue interdisciplinary collaboration (www.sbs.ox.ac.uk/community/school-university/ research-collaborations-across-university). The business school (established in 1996) deliberately seeks to embed itself within the ancient institution, using mechanisms such as the Oxford " $1+1$ MBA," which requires study for an additional specialist master's degree in another department. Saïd's executive education programs draw on philosophers, scientists, and other scholars from across the University of Oxford. Executives find this interdisciplinary approach stimulating as they encounter creative "thought leaders" from diverse settings. Mirroring the distinct Oxford collegial system, where members from all disciplines live and eat together, the online GOTO (Global
Opportunities and Threats Oxford) initiative located within Saïd Business School is a platform that includes current students, faculty from different disciplines including outside the business school, and alumni to discuss some of the most complex issues that the world faces today (https:// goto.sbs.ox.ac.uk).

\section{Individual-Level Influences: Boundary Spanning by Deans and Senior Faculty}

Any change to more interdisciplinary collaboration from business schools also depends on internal leadership, specifically that of the dean and his or her orientation to developing relationships across the university through synthesizing and championing behaviors (Davies, 2016: 909). "If the dean of the school does not believe in the change, it does not matter how hard the faculty staff push in this direction, the change will be blocked as it requires a fundamental shift in commitment in the thinking of the faculty" (ABDC, 2014). Reflecting this, Davies (2015) notes that within their top-10 most critical pressures, business school deans in Australia, Europe, and the United States report a focus on student and faculty recruitment, retention, budgets, and competition rather than on integration within the university. Mark Taylor, however, on taking up the dean's position at Warwick Business School announced the mission to be one of "looking at things differently" (www.youtube.com/watch? $\mathrm{v}=\mathrm{s}-\mathrm{jZupWQtr} 4$ ). Following which, recognizing the strength of the host university in core disciplines of social sciences, he recruited professors from psychology and economics to drive an interdisciplinary initiative in behavioral science, which addresses grand challenges such as those in health around changing public behavior (www.wbs.ac.uk/research/ specialisms/teaching-groups/bs).

It is interesting that AACSB International's 2014-2015 deans' survey indicated that business school deans place a much higher priority on "improving relations with business" compared with "improving relations with other academic departments" (AACSB International, 2015: 44). That is to say, in the United States at least, lowering walls for business interaction seems more important to deans than interacting with other academic departments. Notwithstanding such survey evidence, we note outstanding examples of individual North American deans' dispositions for lowering walls in some business schools. For example, on his arrival as dean in 2011, Ted Snyder announced that his first aspiration for Yale School of 
Management was to be recognized as the business school most involved with its home university. This has led to initiatives such as the encouragement of liberal arts students at Yale to apply for the MBA and a Yale partnership with the National University of Singapore (NUS), which encompasses the flagship interdisciplinary offering, "Learning Across Boundaries (LAB)" in which management students participate (www.yale-nus.edu.sg) (Zakaria, 2015). Roger Martin, formerly dean of Rotman School of Management at the University of Toronto, also brought a particular vision to bear during his deanship, which oriented Rotman more widely toward the host university. Working closely with Procter \& Gamble's CEO on strategy over many years, he wrote a book on the "opposable mind," which reflected his interest in developing integrative forms of design thinking and collaborations with other disciplines (Lafley \& Martin, 2013; Martin, 2009). Martin's vision was manifested in a suite of MBA offerings in particular, which linked to grand challenges, such as global affairs, science and engineering, healthcare and the environment (www.rotman.utoronto.ca).

Meanwhile at faculty level, Terjesen and Politis (2015: 151) argue: "Business schools desperately need polymath scholars who possess knowledge in multiple disciplines and can adapt this expertise across domains." David Gann, vice-president at Imperial College London, holds dual appointments as chair in Innovation and Technology Management at Imperial College Business School and in the Department of Civil and Environmental Engineering. Such boundary-spanning roles facilitate greater academic interconnectedness in interdisciplinary initiatives within the institution. For example, following interdisciplinary conversations at Imperial College, Gerry George (formerly a management professor at Imperial and now dean at Singapore Management University) collaborated on a large-scale project to electrify rural railways in India (Schillebeeckx, Parikh, Bansal, \& George, 2012). Beyond these specific examples, there appear to be new incentives for academics to work across disciplines as governments (such as in the U.K.) provide funding for and encourage the creation of interdisciplinary institutes. At the same time, we highlight countervailing forces, such as promotions criteria, particularly for early and midcareer academics who seek to pursue interdisciplinary activity, but find disciplinary specialism is rewarded in coreer progression (Mosey, Wright, \& Clarysse, 2012). Yet, where such interdisciplinary institutes take hold, later career progression for the polymath scholar may be enhanced (Bozeman \& Boardman, 2013).

\section{TAKING A CONTINGENT VIEW}

Figure 1 brings together the ronge of forces, institutional and otherwise, that influence the height of business school walls. Some forces cause business schools to raise their walls; others to lower them. Generally, we suggest forces for higher walls presently counter those for lower walls and often dominate them, although some recent developments reviewed (e.g., pedagogic reform at the business school level) are strengthening the wall-lowering forces.

As evident in Figure 1, business schools are encouraged to build higher walls by supranational forces of accreditation and rankings, which in turn reinforce epistemic high walls at a disciplinary level. These pressures can be mediated by forces for lower walls at the individual level, particularly the influence of deans who are favorably disposed toward a university-oriented strategic vision. At other levels of influence-national, university, and departmental-the effects upon lower or higher walls are more ambiguous.

Given the mixed set of forces influencing higher or lower walls for business schools, we argue that there is a degree of strategic choice for senior university and business school managers regarding the path they follow. Given our concern about preserving the legitimacy of business schools among their wide range of stakeholders, which we see as threatened when business schools remain isolationist, we ask: "Why do all business schools not follow the lead of those who lower their walls to engage in interdisciplinary collaboration to address grand challenges?"

To a large extent whether business school faculty members can engage in interdisciplinary collaboration is a matter of their capability to do so (Clarysse, Mosey, \& Lambrecht, 2009; Mosey et al., 2012; Wright, Piva, Mosey, \& Lockett, 2009). Wright et al. (2009) provide empirical evidence to show that in the setting of entrepreneurship and technology management when the business school is well integrated with the rest of the university and its faculty are motivated to interact with technology transfer offices and science departments, academics in other departments seeking managerial advice are more likely to turn to the business school. The authors also suggest any capability deficit for interdisciplinary collaboration might be bridged through recruitment of boundary spanners into business schools, such as in-patriated scientists or research- and education-savvy practitioners drawn from the ranks of MBA students. 
RAISING WALLS

\section{Supranational}

- Accrediting agencies and rankings result in mimetic isomorphism and conservatism, perpetuating status quo of élite schools.

- Accreditation criteria require "reasonable" autonomy for B-schools within universities.

- Journal lists privilege narrow disciplinary specialization and discourage interdisciplinarity.

\section{National}

- Government policy around national rankings is based on narrowly defined subject domains.

\section{Intra-University}

- B-school sub-brand hype, cash cow status, high professorial salaries (attracting other disciplines) generate envy from members of other departments.

- Alternative providers of business education force B-schools to behave in grandiose ways ('more 'business', less 'school'") that alienate university faculty who may regard B-schools as intellectually inferior trade schools.

\section{Department}

- B-school pluralism, size (especially following mergers) and in-house collaborations reduce the need for crossuniversity partnerships.

- Resistance to institutional centralization because B-schools support popular programs, diverse students and corporates with differentiated services that require additional resources and flexible staffing.

- Cash cow status results in defensive behaviors.

\section{BUSINESS CHOOL WALLS \\ LOWERING WALLS \\ National}

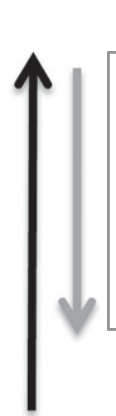

interdisciplinary and nontraditional approaches, including training programs outside their disciplines for social scientists.

- National research policy and funding based on broad themes for universities.
- Governments encourage

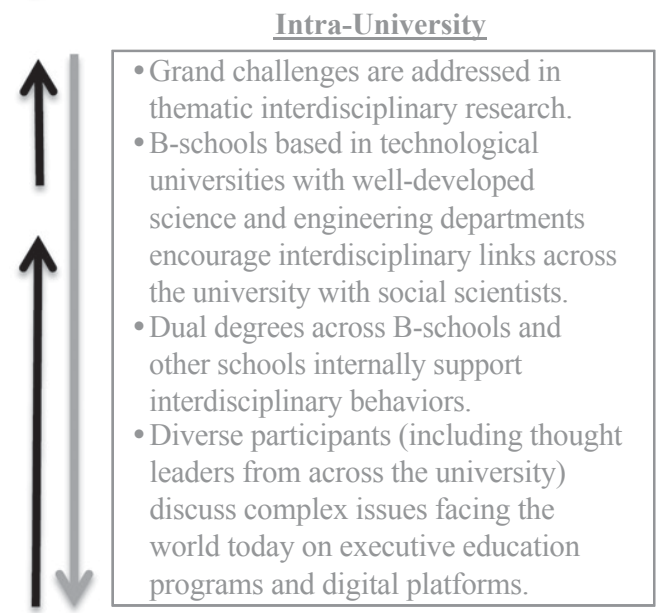

Individual

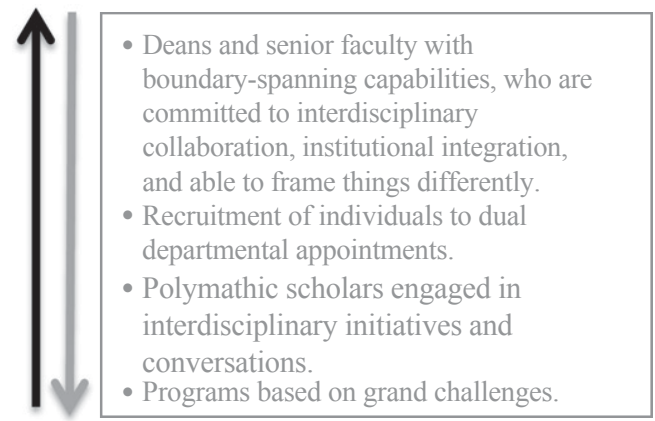

\section{$\underline{\text { Academic Disciplines }}$}

- Epistemic differences: B-school faculty regarded as inferior.

- Other disciplines might absorb B-school activities.

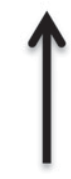

FIGURE 1

Forces Raising and Lowering Business School Walls

Clarysse et al. (2009) focus on the field of innovation and entrepreneurship. Although they recognize a capability deficit among faculty to deliver interdisciplinary teaching innovation, they suggest business schools' capability to lower their walls may be enhanced where they move away from traditional products such as the MBA (about general business, commonly case-based). In its place, they suggest business schools respond to rising client demand (organizations and individual students) by offering 
"boot camps," which are interdisciplinary, to address the grand challenges associated with technology, innovation, and entrepreneurship. This reflects their more general argument that curriculum reform is necessary to enable interdisciplinary collaboration.

Generally, the commentators above are optimistic that business schools enjoy some agency, which can be used to shape prospects for interdisciplinary collaboration, at least in the entrepreneurship, innovation, and technology fields. Although we observe that some of their optimism is fueled by their own positive experiences as faculty members at Nottingham University Business School (which houses the Hadyn Green Institute for Innovation and Entrepreneurship [HGI], http://www.nottingham.ac. uk/business/BusinessCentres/HGI/index.aspx), structural challenges are evident. Note that many of our illustrations of business schools lowering their walls come from élite institutions that possess strong financial and intellectual resources at university and business school levels. Perhaps it is only the more richly endowed, larger, and stronger universities and their departments that can pursue interdisciplinary experimentation. For example, Oxbridge within the United Kingdom or wealthy U.S. Ivy League business schools such as Harvard have advantages in terms of finance, facilities, and well-connected alumni to facilitate interesting collaborations. Institutions without such resources may find interdisciplinary collaboration more challenging. For example, at the University of California San Diego (UCSD), the espoused strategic intent of Rady School of Management was to bring together departments of science and engineering to develop "bicultural and bilingual" students within business and management education. However, the financing for such on initiative proved so challenging that success was partial at best (Starkey \& Tiratsoo, 2007).

\section{CONCLUDING DISCUSSION}

Our (analytic) aim has been to examine influences upon the height of the walls between university-based business schools and other academic departments, and also (more normatively) to exhort business schools to lower their walls in pursuit of interdisciplinary collaboration toward public interest-oriented research focused on "grand challenges," and so enhance their legitimacy. We suggest, however, that many business schools appear "off the pace" in lowering their walls, often responding more to supranational-level influences of accreditation and rankings, pressures within the university, and suffering from epistemic challenges, rather than collaborating with longer established disciplines to provide research of greater social value.

Will business schools face a loss of legitimacy among stakeholders if they remain off the pace in lowering their walls? Certainly, they may be displaced by more interdisciplinary thinking that is going on in other academic departments and also from leading edge think tanks which are emerging as alternative and more creative interdisciplinary knowledge producers, for example, in areas such as the digital economy (Oxford Digital Institute; NESTA, [National Endowment for Science, Technology and the Arts in the United Kingdom]); social innovation and entrepreneurship (The Young Foundation); and the grand challenges of climate change and energy policy (Martin Institute, Oxford); poverty (Center for Poverty Research, UC Davis); and healthcare (the University of Michigan's Health Management Research Center based in the School of Kinesiology). Even perceived core business school activity may be relocated elsewhere following business schools' failure to respond to grand challenges, for example at New York University (NYU), leadership development programs and research take place at the Wagner Graduate School for Public Service.

Although the pervasive influence of forces for higher walls means empirical examples are relatively thin on the ground in terms of sustained collaboration between business schools and other academic departments, nevertheless, we remain confident that progress might be made in this direction. We have cited some success stories that we hope will inspire others. We repeat our call to arms for greater business school collaboration with other academic departments to respond to the grand challenges related to disruptive global developments, which are profoundly interdisciplinary in nature. Deans of university-based business schools need to mitigate isolationist tendencies and instead encourage engagement with many other different departments, and much more actively, so as not to appear tired and even passé. Our fear, should business schools fail to lower their walls and not collaborate with other academic departments, is that they will not be accorded a position of strategic intellectual influence within the university, economy, or beyond.

Theoretically, our analysis extends insights around a public interest-oriented model for business schools. Notwithstanding the absence of empirical analysis, Ferlie et al. (2010) highlight the possible diversity of business schools and suggest there are differential opportunities for business schools to 
reimagine their futures along public interest lines. Our analysis identifies some contingencies within and around business schools that shape interdisciplinary collaboration toward the public interest model and provides empirical illustrations in so doing.

Regarding further research, given the surge of interest in interdisciplinary collaboration more generally across other disciplines (Aldrich, 2014; Barry \& Born, 2014; Frodeman, Klein, \& Mitcham, 2012; Graff, 2015; Jacobs, 2014; O'Rourke, Crowley, Eigenbrode, \& Wulfhorst, 2013; Weingart \& Padberg, 2014), the time is ripe to explore how business school scholars negotiate and realize valuable interdisciplinary collaboration with colleagues inside the university. What more success stories are there to report? Why and how has interdisciplinary collaboration between business schools and other academic departments evolved, and what has been its impact? More specifically, we noted that our illustrations of lowering walls mainly derive from élite institutions, thus we encourage further research that considers a larger and more representative cohort of business schools or universities beyond this élite group to map potentially diverse responses to opportunities for interdisciplinary collaboration (Pettigrew, 2014).

\section{REFERENCES}

AACSB International. 2013. AACSB International business accreditation standards comparison 2013. Tampa, FL: AACSB International.

AACSB International. 2015. What it means to be dean. BizEd. Tampa, FL: AACSB, February 26.

ABDC (Australian Business Deans Council). 2014. The future of management education. Sydney: ABDC.

Adler, N., \& Harzing, A.-W. 2009. When knowledge wins: Transcending the sense and nonsense of academic rankings. Academy of Management Learning \& Education, 8: 72-95.

Adler, P. S. 2002. Corporate scondals: It's time for reflection in business schools. The Academy of Management Perspectives, 16: 148-149.

Alajoutsijörvi, K., Juusola, K., \& Siltaoja, M. 2015. The legitimacy paradox of business schools: Losing by gaining. Academy of Management Learning \& Education, 14: 277-291.

Aldrich, J. H. (Ed.), 2014. Interdisciplinarity: Its role in a disciplinebased academy. Oxford, U.K.: Oxford University Press.

Alvesson, M. 2013. The triumph of emptiness: Consumption, higher education, and work organization. Oxford, U.K.: Oxford University Press.

Arbaugh, J. B. 2010. Introduction: And now for something completely different: Business school envy? Academy of Management Learning \& Education, 9: 280-281.

Armstrong, M. J. 2003. Students as clients: A professional services model for business education. Academy of Management Learning \& Education, 2: 371-374.
Augier, M. A., \& March, J. 2011. The roots, rituals, and rhetorics of change: North American business schools after the Second World War. Stanford, CA: Stanford University Press.

Barry, A., \& Born, G. 2014. Interdisciplinarity: Reconfiguration of the social and natural sciences. Abingdon, U.K.: Routledge.

Becher, T. 1989. Academic tribes and territories. Milton Keynes, U.K.: Open University Press.

Becher, T. 1994. The significance of disciplinary differences. Studies in Higher Education, 19: 151-161.

Bennis, W. G., \& O'Toole, J. 2005. How business schools lost their way. Harvard Business Review, 83(5): 96-104.

BIS (Department for Business Innovation \& Skills). 2011. Innovation and research strategy for growth. London: Department for Business Innovation \& Skills.

Boyde, E. 2013. AACSB overhauls its accreditation standards. The Financial Times, April 9.

Bozeman, B., \& Boardman, C. 2013. Academic faculty in university research centers: Neither capitalism's slaves nor teaching fugitives. The Journal of Higher Education, 84: 88-120.

Bradshaw, D. 2013. Reims and Rouen business school merger finalised. The Financial Times, April 25.

Bradshaw, D. 2014. The rise of China's entrepreneurial spirit. The Financial Times, December 7.

British Institute of Management. 1963. The making of managers. London, U.K.: BIM.

Callie, T. M., \& Cheslock, J. J. 2008. The hiring and compensation practices of business school deans. The Review of Higher Education, 32: 25-49.

Campbell, L. 2005. Overcoming obstacles to interdisciplinary research. Conservation Biology, 19: 574-577.

Carlile, P. R., Davidson, S. H., Freeman, K. W., Thomas, H., \& Venkatraman, N. (Eds.), 2016. Reimagining business education: Insights and actions from the business education jam. Bingley, U.K.: Emerald.

Choi, B. C. K., \& Pak, A. W. P. 2007. Multidisciplinarity, interdisciplinarity and transdisciplinarity in health research, services, education and policy: Promoters, barriers and strategies of enhancement. Clinical and Investigative Medicine. Medecine Clinique et Experimentale, 30: E224-E232.

Clark, P. 2014. A struggling business school's long, strange saga gets another twist. Bloomberg Businessweek, July 7.

Clarysse, B., Mosey, S., \& Lambrecht, I. 2009. New trends in technology management education: A view from Europe. Academy of Management Learning \& Education, 8: 427-443.

Craig, R. J., Clorke, F. L., \& Amernic, J. H. 1999. Scholorship in university business schools - Cardinal Newman, creeping corporatism and farewell to the 'disturber of the peace?' Accounting, Auditing \& Accountability Journal, 12: 510-524.

Cruikshank, J. 1987. Delicate experiment: Harvard Business School, 1908-45. Boston, MA: Harvard Business School Press.

Currie, G. 2007. Beyond our imagination: The voice of international students on the MBA. Management Learning, 38: 539-556.

Currie, G., Dingwall, R., Kitchener, M., \& Waring, J. 2012. Let's dance: Organization studies, medical sociology and health policy. Social Science \& Medicine, 74: 273-280. 
Currie, G., El Enany, N., \& Lockett, A. 2014. Intra-professional dynamics in translational health research: The perspective of social scientists. Social Science \& Medicine, 114: 81-88.

Currie, G., \& Knights, D. 2003. Reflecting on a critical pedagogy in management education. Management Learning, 34: 27-49.

Currie, G., Knights, D., \& Starkey, K. 2010. A post crisis critical reflection on business schools. British Journal of Management, 21: S1-S5.

Davis, E. 2014. A profitable position. Tampa, FL: AACSB International, Retrieved from http://aacsbblogs.typepad.com/ dataandresearch/faculty-and-administrator-salary-data/.

Davies, J. 2015. Reflections on the role of the business school dean. London, U.K.: Chartered Association of Business Schools.

Davies, J. 2016. Are business school deans doomed? The global financial crisis, Brexit and all that. Journal of Management Development, 35: 901-915.

Dunne, S., Harvey, S., \& Parker, M. 2008. Speaking out: The responsibilities of management intellectuals: A survey. Organization, 15: 271-282.

EFMD. 2015. EFMD quality improvement system. The EFMD accreditation for international business schools. Brussels, Belgium: EFMD.

Ferlie, E., Currie, G., Davies, J., \& Ramadan, N. 2014. Business schools inside the academy: Prospects for inter-departmental research collaboration. In A. M. Pettigrew, E. Cornuel, \& U. Hommel (Eds.), The institutional development of business schools: 221-247. Oxford, U.K.: Oxford University Press.

Ferlie, E., McGivern, G., \& De Moraes, A. 2010. Developing a public interest school of management. British Journal of Management, 21: S60-S70.

Flyvbjerg, B. 2001. Making social science matter. Cambridge, U.K.: Cambridge University Press.

Frodeman, R., Klein, J., \& Mitcham, C. (Eds.), 2012. The Oxford handbook of interdisciplinarity. Oxford, U.K.: Oxford University Press.

Ghoshal, S. 2005. Bad management theories are destroying good management practices. Academy of Management Learning \& Education, 4: 75-91.

Gioia, D. A., \& Corley, K. G. 2002. Being good versus looking good: Business school rankings and the Circean transformation from substance to image. Academy of Management Learning \& Education, 1: 107-120.

Gordon, R., \& Howell, J. 1959. Higher education for business. New York, NY: Columbia University Press.

Groff, H. J. 2015. Undisciplining knowledge: Interdisciplinarity in the twentieth century. Baltimore, MD: Johns Hopkins University Press.

Green, M. 2009. Merger with innovation at its heart. The Financial Times, March 29.

Grey, C. 2004. Reinventing business schools: The contribution of critical management education. Academy of Management Learning \& Education, 3: 178-186.

Griffiths, B., \& Murray, H. 1985. Whose business? A radical proposal to privatize British business schools. Hobart Paper No. 102. London, U.K.: Institute of Economic Affairs.

Ivory, C., Miskell, P., Neely, A., Shipton, H., \& White, A. 2007. The future of business school faculty. London, U.K.: Advanced Institute of Management Research.
Jacobs, J. A. 2014. In defense of disciplines: Interdisciplinarity and specialization in the research university. Chicago, IL: University of Chicago Press.

Jacobs, J. A., \& Frickel, S. 2009. Interdisciplinarity: A critical assessment. Annual Review of Sociology, 35: 43-65.

Julian, S. D., \& Ofori-Dankwa, J. C. 2006. Is accreditation good for the strategic decision making of traditional business schools? Academy of Management Learning \& Education, 5: 225-233.

Khazragui, H., \& Hudson, J. 2015. Measuring the benefits of university research: Impact and the REF in the UK. Research Evaluation, 24: 51-62.

Khurana, R. 2007. From higher aims to hired hands: The social transformation of American business schools and the unfulfilled promise of management as a profession. Princeton, NJ: Princeton University Press.

Knorr-Cetina, K. 1999. Epistemic cultures: How the sciences make knowledge. Cambridge, MA: Harvard University Press.

Lafley, A. G., \& Martin, R. 2013. Playing to win: How strategy really works. Boston, MA: Harvard Business Review Press.

Larson, M. S. 1979. The rise of professionalism: $A$ sociological analysis. Berkeley, CA: University of California Press.

Laumann, E. O., Gagnon, J. H., Michael, R. T., Michaels, S., \& Sennett, R. 1995. 'Sex, lies, and social science': An exchange. The New York Review of Books, 42(9): 43-44.

Lejeune, C., \& Vas, A. 2014. Institutional pressure as a trigger for organizational identity change: The case of accreditation failure within seven European business schools. In A. M. Pettigrew, E. Cornuel, \& U. Hommel (Eds.), The institutional development of business schools: 95-125. Oxford, U.K.: Oxford University Press.

Lejeune, C., Davies, J., \& Starkey, K. 2015. The impact of the impact agenda. Global Focus, 9(2): 44-47.

Lloyd-Jones, R., \& Lewis, M. J. 1998. British industrial capitalism during the second industrial revolution: A Schumpeterian approach. Journal of Industrial History, 1: 73-110.

Locke, R., \& Spender, J.-C. 2011. Confronting managerialism. How the business élite and their schools threw our lives out of balance. London, U.K.: Zed Books.

Lowe, R. 2011. The official history of the British civil service. Reforming the Civil Service: The Fulton years, 1966-81, Vol. 1. Abingdon, U.K.: Routledge.

Lowrie, A., \& Willmott, H. 2009. Accreditation sickness in the consumption of business education: The vacuum in AACSB standard setting. Management Learning, 40: 411-420.

Martin, R. L. 2009. Opposable mind. Boston, MA: Harvard Business Review Press.

McKiernan, P., \& Wilson, D. 2014. Strategic choice: Taking 'business' out of B-Schools. In A. M. Pettigrew, E. Cornuel, \& U. Hommel (Eds.), The institutional development of business schools: 248-269. Oxford, U.K.: Oxford University Press.

Morsing, M., \& Rovira, A. S. (Eds.), 2013. Business schools and their contribution to society. London: Sage.

Mosey, S., Wright, M., \& Clarysse, B. 2012. Transforming traditional university structures for the knowledge economy through multi-disciplinary institutes. Cambridge Journal of Economics, 36: 587-607. 
Muff, K., Dyllick, T., Drewell, M., North, J., Shrivastava, P., \& Haertle, J. 2013. Management education for the world: A vision for business schools serving people and planet. Cheltenham, U.K.: Edward Elgar.

Navarro, P. 2008. The MBA core curricula of top-ranked US business schools: A study in failure? Academy of Management Learning \& Education, 7: 108-123.

O'Rourke, M., Crowley, S., Eigenbrode, S. D., \& Wulfhorst, J. D. 2013. Enhancing communication \& collaboration in interdisciplinary research. Thousand Oaks, CA: Sage.

Parker, M. 2015. Between sociology and the business school: Critical studies of work, employment and organization in the UK. The Sociological Review, 63: 162-180.

Parsons, T. 1951. The social system. Glencoe, IL: Free Press.

Pettigrew, A. M. 2014. Building a research agenda for the institutional development of business schools. In A. M. Pettigrew, E. Cornuel, \& U. Hommel (Eds.), The institutional development of business schools: 294-312. Oxford, U.K.: Oxford University Press.

Pettigrew, A. M., Cornuel, E., \& Hommel, U. (Eds.), 2014. The institutional development of business schools. Oxford: Oxford University Press.

Pfeffer, J., \& Fong, C. T. 2004. The business school 'business': Some lessons from the US experience. Journal of Management Studies, 41: 1501-1520.

Pierson, F. C. 1959. The education of American businessmen. New York, NY: McGrow-Hill.

Pieters, R., \& Baumgartner, H. 2002. Who talks to whom? Intra- and interdisciplinary communication of economics journals. Journal of Economic Literature, 40: 483-509.

Podolny, J. M. 2009. The buck stops (and starts) at business school. Harvard Business Review, 87(6): 62-67.

Porter, L. W., \& McKibbin, L. E. 1988. Management education and development: Drift or thrust into the 21st century? New York, NY: McGraw-Hill.

Proitz, T. S., Stensaker, B., \& Harvey, L. 2004. Accreditation, standards and diversity: An analysis of EQUIS accreditation reports. Assessment \& Evaluation in Higher Education, 29: 735-750.
Rasche, A., Hommel, U., \& Cornuel, E. 2014. Discipline as institutional maintenance: The case of business school rankings. In A. M. Pettigrew, E. Cornuel, \& U. Hommel (Eds.), The institutional development of business schools: 196-220. Oxford, U.K.: Oxford University Press.

Schillebeeckx, S. J. D., Parikh, P., Bansal, R., \& George, G. 2012. An integrated framework for rural electrification: Adopting a user-centric approach to business model development. Energy Policy, 48: 687-697.

Starkey, K. 2015. The strange absence of management during the current financial crisis. Academy of Management Review, 40: 652-663.

Starkey, K., \& Tiratsoo, N. 2007. The business school and the bottom line. Cambridge, U.K.: Cambridge University Press.

Starkey, K., Hatchuel, A., \& Tempest, S. 2009. Rethinking the business school. Journal of Management Studies, 41: 1521-1531.

Tallon, D. 1959. A foreign viewpoint on American business schools. Michigan Business Review, Xl(2): 29-32.

Terjesen, S., \& Politis, D. 2015. From the editors: In praise of multidisciplinary scholarship and the polymath. Academy of Management Learning \& Education, 14: 151-157.

Thomas, H., \& Wilson, A. D. 2009. An analysis of the environment and the competitive dynamics of management research. Journal of Management Development, 28: 668-684.

Wedlin, L. 2007. The role of rankings in codifying a business school template: Classifications, diffusion and mediated isomorphism in organizational fields. European Management Review, 4: 24-39.

Weingart, P., \& Padberg, P. (Eds.), 2014. University experiments in interdisciplinarity: Obstacles and opportunities. Bielefeld, Germany: Transcript Verlag.

Whitley, R. 1988. The management sciences and managerial skills. Organization Studies, 9: 47-68.

Wright, M., Piva, E., Mosey, M., \& Lockett, A. 2009. Academic entrepreneurship and business schools. The Journal of Technology Transfer, 34: 560-587.

Zakaria, F. 2015. In defense of a liberal education. New York, NY: W.W. Norton \& Company, Inc.

Graeme Currie (graeme.currie@wbs.ac.uk) is pro-dean research and professor of public management at Warwick Business School in the United Kingdom. He earned his $\mathrm{PhD}$ at the University of Nottingham in the UK. Graeme leads the "Implementation Science \& Organisation Studies" research program for CLAHRC West Midlands, funded by the National Institute for Health Research (NIHR). Graeme's research interests include leadership, knowledge mobilization, innovation, strategic change, and management learning in public services.

Julie Davies (j.a.davies@hud.ac.uk) is HR subject group leader at the University of Huddersfield Business School in the United Kingdom. She received her PhD from Warwick University. Julie is a member of the Interdisciplinary Research on Management Education group at the University of Jyväskylä, Finland, and on IAE Lyon's international advisory board. She collaborates with EU research partners on HRM in SMEs. Julie's research interests focus on business schools, research impact, faculty development and autoethnography.

Ewan Ferlie (ewan.ferlie@kcl.ac.uk) is professor of public services management in the School of Management and Business, King's College London, and a Fellow of the British Academy. He gained his $\mathrm{PhD}$ at the University of Kent, in the United Kingdom. Ewan's research includes the organization and management of public services, the enactment of evidence into professional and managerial practice, change management, knowledge transfer, and organizational networks. 
Copyright of Academy of Management Learning \& Education is the property of Academy of Management and its content may not be copied or emailed to multiple sites or posted to a

listserv without the copyright holder's express written permission. However, users may print, download, or email articles for individual use. 